\title{
Portrait of the Cape honeybee, Apis mellifera capensis
}

\author{
HR Hepburn ${ }^{1 *}$, RM Crewe 2 \\ 1 Rhodes University, Department of Zoology and Entomology, Grahamstown; \\ 2 University of Witwatersrand, Department of Zoology, Johannesburg, South Africa
}

(Received 9 July 1991; accepted 21 October 1991)

\begin{abstract}
Summary - The honeybees of southern Africa were assessed for expression of the trait, diploid eggs laid by workers, worker ovariole number, spermatheca size, worker size and allozymes of malate dehydrogenase. A $m$ capensis is readily defined in terms of the first 2 of these traits and may further be separated from $A m$ scutellata by a suite of biological characteristics associated with laying worker development and behaviour, queenless cell building, foraging, thermoregulation and docility. The Cape honeybee occurs in the fynbos biome along the southwest and south coasts of South Africa extending into the interior as far as the mountains bordering on the Klein Karoo. From here it hybridizes with $A m$ scutellata to the next mountain ranges near latitude 32 where hybrids fall away. This border is a barrier where there are fundamental differences in topography, climate and vegetation which place the 2 races ecologically totally out phase and ensure the relative stability of $A \mathrm{~m}$ ca. pensis and $A m$ scutellata as separate races.
\end{abstract}

\section{A $\boldsymbol{m}$ capensis / behaviour / A m scutellata / biotope / review article}

\section{INTRODUCTION}

The remarkable honeybee trait, thelytoky by workers, was discovered in Cape honeybees by Onions $(1912,1914)$ and has often been confirmed (Kerr and Portugal Araujo, 1958; Anderson, 1963; Ruttner, 1988). Further studies have revealed the pheromonal (Ruttner et al, 1976; Hemmling et al, 1979; Crewe and Velthuis, 1980; Velthuis et al, 1990) and biological versatility of Cape bees (Hepburn et al, 1988; Ruttner, 1988; Crewe et al, 1991), yet its definition and precise distribution remained elusive. In attempting to resolve the problem of defining so biologically distinct a race as capensis by traditional taxonomic methods, 3 biological traits have been identified: the occurrence in worker bees of i) the trait diploid eggs (thelytoky) laid by workers (DELW); ii) a well developed spermatheca; and iii) many ovari-

* Correspondence and reprints 
oles per ovary (Kerr and Portugal Araujo, 1958; Ruttner, 1977). This new approach led to the view that unhybridized capensis was possibly restricted to the Cape Peninsula with transitory forms to the north and east (Moritz and Kauhausen, 1984; Ruttner, 1988). The important work of Ruttner (1977, 1988), coupled to recent discoveries that honeybees of the eastern Cape are actually capensis-like (Hepburn et al, 1988; Hepburn, 1989), led to a reexamination of this race (Hepburn and Crewe, 1990; Hepburn and Jacot Guillarmod, 1991) and, ultimately, to this review of the Cape honeybee.

\section{METHODS}

We sampled the worker honeybees of southern Africa (table I, fig 1) and measured ovariole number, spermatheca size, body size and surface area of the mandibular gland. Data were collected from 20 workers per colony from about 6 colonies per locale. In loco measurements of the sex ratios (male progeny: female worker progeny) of laying worker progeny in queenless, broodless colonies pinpointed the distribution of the trait 'diploid eggs laid by workers' (DELW). These ratios should not be confused with those of normal reproductives (queen honeybees). Allelic and genotypic frequencies of isozymes of malate dehydrogenase were determined using isoelectric focusing (Nunamaker and Wilson, 1981). The 'sizes' of workers were assessed on the basis of constant dry weight values. Statistical analyses included the Kruskal-Wallis 1-way ANOVA ( $H$ values) and the calculation of Pearson's correlation coefficients. Significance is defined as $P<0.05$.

\section{RESULTS}

The distribution of the trait DELW is crucial to the definition of capensis (Ruttner, 1988) and the sex ratios of known laying worker progeny (expression of DELW) are

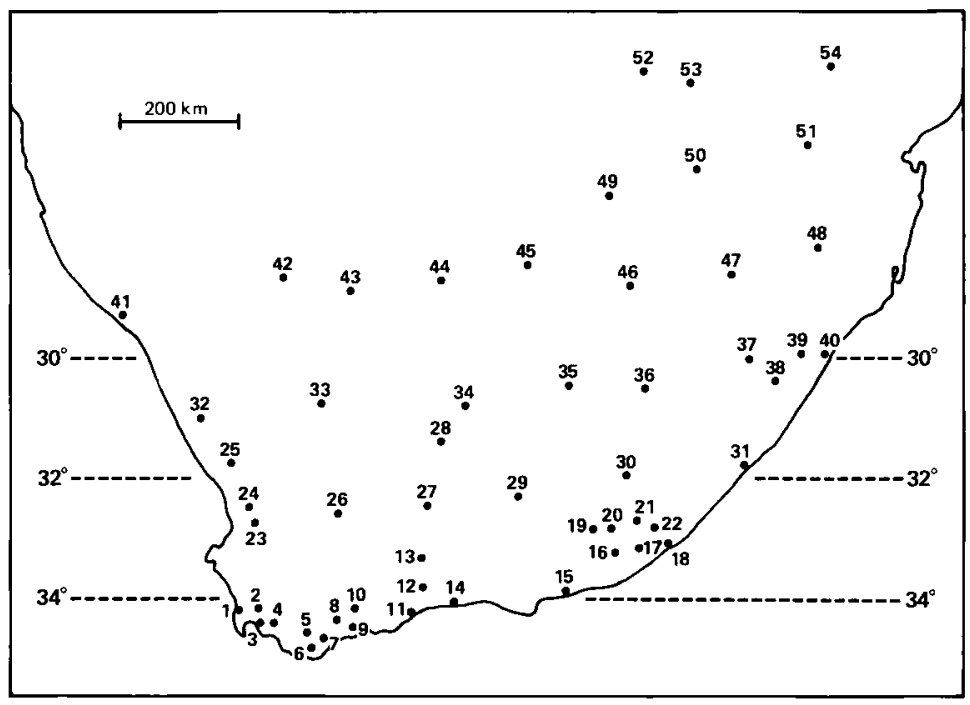

Fig 1. Localities in southern Africa at which honeybee colonies were assessed for the sex ratios of laying worker progeny, ovariole number, spermatheca size and bee dry weights. Results are given in table I. 
given in table I. DELW extends along the seaward side of the mountains from about Calvinia-Vanrhynsdorp (locality 33 ) in the southwest, around the southern coast to about East London (locality 18) in the east (table I, fig 1). In the interior it is bounded by the Nuweveld and Stormberg mountain ranges (line joining locality points $33,26-$ 30 of figure 1; mountains 5-9, fig 2). Grouping the sex ratio (M/F) data into pure capensis, mixed and scutellata, 3 areas can be distinguished, respectively: i) a Cape Town-East London zone (fig 1, points 1-18), ii) a Clanwilliam-Queenstown zone (24-30) and iii) all points north of latitude 32 (fig 1). The relationship of the sex ratio of laying worker progeny to area (distinctness of groups) is highly significant $(H=11.8$, df $=2$ and $P<0.002)$.

The distribution of ovariole number for about 5000 workers representing 45 localities is given in table I. Using the DELW zones, average ovariole number is about 12 in the first zone, 9 in the second and north of latitude 32 (classical scutellata area) it drops to 3 ovarioles/ovary (table I). These 3 groups are significantly different from one another $(\mathrm{H}=29.4$, df $=2, P<$ 0.05 ). Moreover, the 3 groups based on ovariole number match those based on the sex ratios of laying worker progeny $(\mathrm{H}=$ 11.8, $\mathrm{df}=2, P<0.002$ ). Variance for ovariole numbers (Hepburn and Crewe, 1990) significantly decreased $(H=14.91$, $\mathrm{df}=2, P<0.05$ ) between zone 1 and 2 and between zone 2 and above latitude 32 , or from south to north.

Data on spermatheca size for about 2500 bees representing 45 localities (table I) show that large spermathecae occur in the Cape Peninsula (localities 1-3) but so do small ones (localities 7 and 8). Spermathecae larger than those found at the Cape Peninsula occur further east along

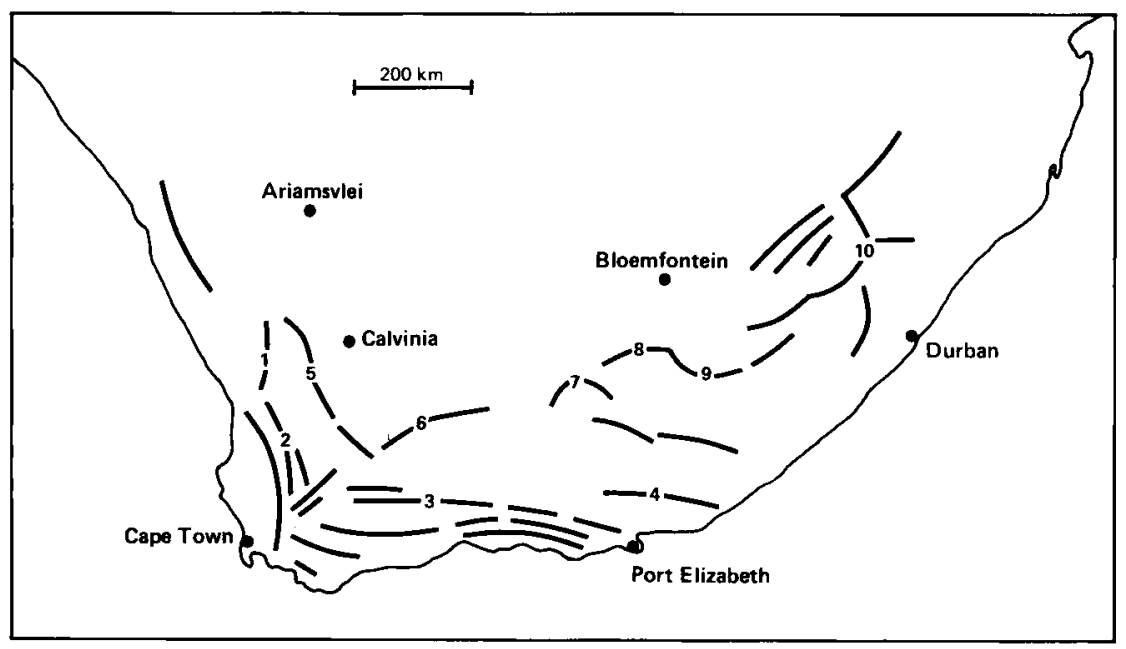

Fig 2. Geographical distribution of $A m$ capensis in relation to $A m$ scutellata and the major mountain ranges of southern Africa. Capensis occurs in the fynbos biome along the southwest and south coasts extending to the: 1, Bokkeveld; 2, Cedarberg; 3, Swartberg; and 4, Suurberg mountains. Scutellata extends southwards to the: 5 , Roggeveldberg; 6 , Nuweveldberg; 7 , Sneeuberg; 8 , Kikvorsberg and Bamboesberg; 8, Stormberg; and 10, Drakensberg mountain ranges. The zone of hybridization between capensis and scutellata is the region lying between mountain ranges $1-4$ and 5-10. 
Table I. Distribution of the gene DELW, ovariole number, spermatheca size and constant dry weight of worker honeybees in southern Africa a.

\begin{tabular}{|c|c|c|c|c|}
\hline Locality & $\begin{array}{l}\text { Laying worker b } \\
\text { progeny sex } \\
\text { ratio }(M / F)\end{array}$ & $\begin{array}{l}\text { Ovariole }{ }^{c} \\
\text { number }\end{array}$ & $\begin{array}{l}\text { Spermathecad } \\
\text { size }(\mu \mathrm{m})\end{array}$ & $\begin{array}{l}\text { Dry weight } \\
\text { (mg) }\end{array}$ \\
\hline 1. Cape Town & $a+$ & $17.4 \pm 4.9$ & $21 \pm 4$ & $1.6 \pm 0.3$ \\
\hline 2. Stellenbosch & $a+$ & 18.2 & $((44))$ & - \\
\hline 3. Somerset West & $a+$ & - & & - \\
\hline 4. Grabouw & $a+?$ & 12.7 & & - \\
\hline 5. Fairfield & $a+?$ & 11.1 & $(1)$ & - \\
\hline 6. Elim & $a+?$ & 11.4 & $(15)$ & - \\
\hline 7. Bredasdorp & $a+?$ & 8.9 & 26 & - \\
\hline 8. Malgas & $a+?$ & 10.7 & 17 & - \\
\hline 9. Witsand & $a+?$ & 12.0 & 42 & - \\
\hline 10. Heidelberg & $a+?$ & $12.6 \pm 4.1$ & $(20 \pm 4)$ & $1.8 \pm 0.2$ \\
\hline 11. Mossel Bay & $a+?$ & 6.8 & & - \\
\hline 12. Oudtshoorn & $a+?$ & 10.1 & 27 & - \\
\hline 13. Prince Albert & $a+?$ & 14.9 & 15 & - \\
\hline 14. Knysna & $a+$ & $11.8 \pm 2.9$ & $13 \pm 2$ & $2.0 \pm 0.4$ \\
\hline 15. Port Elizabeth & $a+$ & $12.5 \pm 2.8$ & $15 \pm 2$ & $1.0 \pm 0.8$ \\
\hline 16. Alicedale & $\mathbf{a}$ & - & - & - \\
\hline 17. Grahamstown & $\mathbf{a}$ & - & - & - \\
\hline 18. East London & $a=b$ & $7.1 \pm 2.0$ & $14 \pm 3$ & $2.3 \pm 0.4$ \\
\hline 19. Longhope & a & - & - & - \\
\hline 20. Bedford & $a$ & - & - & - \\
\hline 21. Fort Beaufort & $a$ & - & - & - \\
\hline 22. Dudumashe & $b+$ & - & - & - \\
\hline 23. Citrusdal & $a+$ & - & - & - \\
\hline 24. Clanwilliam & $\mathrm{a}$ & $11.5 \pm 5.1$ & $21 \pm 3$ & $1.4 \pm 0.2$ \\
\hline 25. Lutzville & a? & 8.2 & 15 & - \\
\hline 26. Sutherland & a & $6.4 \pm 3.0$ & $21 \pm 2$ & $1.6 \pm 0.3$ \\
\hline 27. Beaufort West & $b$ & $7.9 \pm 3.0$ & $14 \pm 2$ & $1.9 \pm 0.1$ \\
\hline 28. Victoria West & a? & 4.2 & 15 & - \\
\hline 29. Graaff Reinet & $a=b$ & $10.2 \pm 3.1$ & $15 \pm 3$ & $2.1 \pm 0.1$ \\
\hline 30. Queenstown & b & $6.0 \pm 3.2$ & $16 \pm 5$ & $3.4 \pm 1.0$ \\
\hline 31. Port St Johns & $\mathrm{b}+?$ & $1.3 \pm 1.6$ & $14 \pm 4$ & $2.6 \pm 1.4$ \\
\hline 32. Garies & $b+?$ & $2.6 \pm 2.7$ & $14 \pm 4$ & $2.6 \pm 0.9$ \\
\hline 33. Calvinia & $\mathrm{a}$ & $4.3 \pm 2.3$ & $19 \pm 4$ & $2.8 \pm 0.9$ \\
\hline 34. Britstown & $b+$ & $2.7 \pm 1.9$ & $19 \pm 3$ & $4.0 \pm 1.0$ \\
\hline 35. Springfontein & b+ & $4.4 \pm 1.2$ & $14 \pm 2$ & $2.4 \pm 0.6$ \\
\hline 36. Zastron & b+ & $3.8 \pm 2.7$ & $16 \pm 4$ & $3.5 \pm 1.2$ \\
\hline 37. Underberg & $\mathrm{b}+$ & $1.6 \pm 1.2$ & $12 \pm 3$ & $2.0 \pm 0.2$ \\
\hline 38. Ixopo & $b+$ & $2.9 \pm 1.1$ & $14 \pm 3$ & $2.4 \pm 0.6$ \\
\hline 39. Pietermaritzburg & $b+$ & - & - & - \\
\hline 40. Durban & $\mathrm{b}+?$ & $3.2 \pm 1.7$ & $14 \pm 3$ & $2.5 \pm 0.6$ \\
\hline 41. Alexander Bay & $\mathrm{b}+?$ & $2.6 \pm 1.7$ & $14 \pm 4$ & $2.2 \pm 0.6$ \\
\hline 42. Ariamsvlei & $\mathrm{b}+?$ & $3.0 \pm 1.1$ & $16 \pm 7$ & $2.9 \pm 1.0$ \\
\hline 43. Upington & $b+?$ & $2.8 \pm 2.7$ & $14 \pm 3$ & $2.8 \pm 0.5$ \\
\hline 44. Postmasberg & $b+?$ & $3.9 \pm 2.9$ & $17 \pm 4$ & $3.8 \pm 1.3$ \\
\hline
\end{tabular}




\begin{tabular}{|c|c|c|c|c|}
\hline 45. Warrenton & $\mathrm{b}+?$ & $3.3 \pm 1.9$ & $16 \pm 7$ & $3.1 \pm 0.9$ \\
\hline 46. WInberg & $\mathrm{b}+?$ & $2.3 \pm 2.1$ & $15 \pm 4$ & $4.1 \pm 1.0$ \\
\hline 47. Harrismith & $b+?$ & $2.6 \pm 1.1$ & $15 \pm 4$ & $3.7 \pm 1.2$ \\
\hline 48. Vryheid & $b+?$ & $3.1 \pm 1.5$ & $15 \pm 5$ & $2.6 \pm 0.6$ \\
\hline 49. Klerksdorp & $b+?$ & $4.6 \pm 2.3$ & $19 \pm 3$ & $3.0 \pm 0.9$ \\
\hline 50. Nigel & $\mathrm{b}+?$ & $3.3 \pm 1.4$ & $14 \pm 3$ & $3.0 \pm 1$ \\
\hline 51. Badplass & $\mathrm{b}+?$ & $3.5 \pm 1.8$ & $19 \pm 3$ & $2.5 \pm 0.7$ \\
\hline 52. Thabazimbi & $b+?$ & $2.9 \pm 1.6$ & $17 \pm 3$ & $3.3 \pm 1$ \\
\hline 53. Warmbaths & $b+?$ & $3.1 \pm 1.5$ & $18 \pm 5$ & $2.8 \pm 1$ \\
\hline 54. Hoedspruit & $b+?$ & $2.8 \pm 1.2$ & $18 \pm 3$ & $3.0 \pm 1$ \\
\hline
\end{tabular}

a Primary sources given by Hepburn and Crewe (1990); ${ }^{b}$ Laying worker progeny is indicated as: a+ = pure capensis, $\mathrm{a}=$ predominantly capensis, $\mathrm{a}=\mathrm{b}, \mathrm{b}=$ predominantly scutellata, $\mathrm{b}+=$ pure scutellata. When actual sex ratio data for laying worker progeny is missing, based on the position of the localities it is highly likely that the ratios will be as indicated by a "?". The sex ratios referred to here are male : female workers (arrhenotoky : thelytoky). " Values calculated for several data sets at some localities. ${ }^{d}$ Bracketed values are approximate for more than one locality.

the south coast (localities 14 and 15) as well as among scutellata of the Transvaal (localities 49, 51-54) and many other localities. Tests of differences between zones for spermathecae showed them to be not significant $(\mathrm{H}=2.4, \mathrm{df}=2, P<0.05)$; nor was there a correlation between spermatheca size and ovariole number $(r=0.4$ and $r^{2}=18 \%$ ).

To preclude errors from posthumous shrinkage we estimated "size" in bees on the basis of constant dry weight (table I). The bees were heaviest in the north and weighed progressively less to the south. Bee weights from the DELW area are significantly less than those beyond the DELW area, indicating smaller bees to the south. Using the DELW zones, the 3 groups of bee weights were significantly different $(H \neq 14.0$, df $=2, P<0.05)$ and were negatively correlated with ovariole number $(r=0.66)$. Because the volume of the capensis mandibular gland is larger than that of carnica (Ruttner, 1988) the surface area of this gland was assessed but no patterns emerged from this data (Hepburn, 1991).

Of 6 allozyme phenotypes for the Mdh-1 locus in honeybees (Nunamaker and Wil- son, 1981), only 2 were found in the southern African samples and they corresponded with known bands (Nunamaker et al, 1984). Six bees from Cape Town (locality 1) and 2 from Queenstown (locality 30 ) had 3 bands, indicating heterozygosity for $\mathrm{MDH} \mathrm{m} / \mathrm{F}$ (there is historical proof of ligustica introductions at both localities). The homozygous genotype $\mathrm{MDH} \mathrm{M} / \mathrm{M}$ was not detected.

\section{DISCUSSION}

The Mdh-1 locus exhibited a very low degree of polymorphism suggesting that both capensis and scutellata are monomorphic for Mdh-1. However, analysis of mitochondrial DNA has demonstrated that both capensis and scutellata differ from European mellifera (Smith, 1988) and that there are other differences between these 2 African races (Meusel and Moritz, personal communication). The differences between the African races (base pair inserts, table II) may not be diagnostic, but merely represent a high level of variability within the populations.

The spectrum of sex ratios of laying worker progeny encountered in southern 
Africa (table I) raises questions about the genetics of DELW. Onions (1912) reported that ligustica $x$ capensis crosses yielded laying workers whose own progeny was female; but Kerr and Portugal Araujo (1958) obtained mixed sex progeny in similar crosses. Production of mixed progeny could be a result of the production of diploid and haploid eggs by a single individual or it could arise as a result of having a mixed population in which some workers had the DELW trait and others the HELW trait. The latter appears the more likely explanation in view of the mechanism for the expression of the DELW trait (Verma and Ruttner, 1983), but remains uncertain.

Tribe $(1981,1983)$ noted that laying workers of capensis $\mathrm{x}$ scutellata crosses produced workers whose own progeny was female. When this laying worker progeny was used to produce queens for successive scutellata crosses, the new generation of laying workers produced mixed progeny. These results reflect what occurs in nature in zone 2 for DELW in southern Africa. Recently, Ruttner (1988) reported on capensis queens crossed with drones produced from $F_{1}$ queens of a capensis $x$ carnica cross so representing male $F_{2}$ gametes. Although there is a very low but natural frequency of DELW in temperate mellifera races (Mackensen, 1943; Woyke, 1986) the sex ratios of progeny of laying workers in Ruttner's cross were bimodally distributed, suggesting 2 alleles at one locus in capensis (Ruttner, 1988; Moritz, 1991).

On the strength of their measurements, Ruttner $(1977,1988)$ and Moritz and Kauhausen (1984) thought that relatively homogeneous populations of capensis were probably restricted to the Cape Peninsula. The much larger data set now available (table I) indicates that a reasonably homogeneous population, based on DELW and ovariole number, is distributed in zone 1 (fig 1). Although the variance for these features decreases from south to north, the magnitude of the variance within the capensis area lacks the clinal characteristics for ovariole number that occurs in the hybrid zone between capensis and scutellata (table I; Hepburn and Crewe, 1990). The few genes necessary to control the expression of DELW and ovariole number (table I) may not be sufficient to elevate 2 populations to the level of races. However, there is a substantial body of additional biological data which separates capensis from scutellata (table II).

We interpret the full data (tables I and II) to mean that the Cape honeybee, Apis mellifera capensis is a biologically distinct, small, blackish bee race of the fynbos, a biome which extends along the coast of South Africa from about the level of Vanrhynsdorp in the west to somewhere near East London. It extends from the coast into the mountains (1, Bokkeveld; 2, Cedarberg; 3, Swartberg; and 4, Suurberg of figure 2). The African honeybee, Apis mellifera scutellata is a northern race whose southern limit is defined by mountains in the interior (5, Roggeveldberg; 6, Nuweveldberg; 7, Sneeuberg; 8, Kikvorsberg and Bamboesberg; 9, Stormberg and 10, Drakensberg ranges of figure 2). This leaves a corridor or zone of hybridization between the Cape honeybee and the African honeybee of about $200 \mathrm{~km}$ breadth running between the Cape Fold mountains in the south and the Nuweveldberge and Drakensberge to the north (fig 2).

Given the distribution of capensis, scutellata and the hybrid zone between them, the origins of these 2 races, the stability and homogeneity of their populations and possible barriers that maintain them are of considerable theoretical and practical interest. These points can be at least partially realized by considering the physical and biological factors of their respective regions 
(table III). The fynbos is a macchia-like biome of unique plant forms contained within about $70000 \mathrm{~km}^{2}$, the world's smallest floral kingdom (Bond and Goldblatt, 1984). Geologically the fynbos occurs in a belt of folded mountains of preGondwanan origin which have been stable for about 65 million years. They descend sharply into coastal plains which experienced some 60 million years of periodic marine inundation. This contrasts sharply with the Great Karoo to the north which was defined by warping of the continental plate some 60 million years ago, and led to the shunting of all drainage to the north and leaving an arid region behind (Deacon et al, 1983).

The climates stabilized some 5 million years ago but included 0.1 million year cycles of glaciation, the last of which began some 70000 years ago and ended perhaps 10000 years ago (Deacon and Lancaster, 1988). The movements of plants and animals during interglacial periods and their isolation during glaciation in southern Africa are well documented (Deacon et al, 1983). Any of the cycles of Pleistocene glaciation in southern Africa could have isolated honeybee populations (Deacon and Lancaster, 1988) over time scales that have been proposed for the evolution of honeybee races (Ruttner, 1988).

The fynbos occurs on a patchwork of poorly differentiated soils unlike the welldeveloped latosols and clays the interior of the country (Lambrechts, 1979). Temperatures of the former region are moderate, those of the latter more severe and extreme (Schulze, 1965). Precipitation in the fynbos changes from winter rainfall in the west to evenly distributed in the east while that of the interior comes in summer (Schulze, 1965). The fynbos is a region of winds that regularly change seasonally unlike the highly variable ones in the interior karoo system (table III). Superimposed on these landscapes are totally different vegetative systems. The fynbos has great floristic diversity and endemism whose flowering cycles match that of changing patterns of precipitation along an east-west gradient (Hepburn and Jacot Guillarmod, 1991). This stands in total contrast to that of the Nama-Karoo and Grassland biomes to the north (Rutherford and Westfall, 1985).

Significant features in the biology of the Cape honeybee such as brood cycles, winter migrations, swarming season, thermoregulation and foraging techniques (table II) are finely attuned to the cycles of flowering and precipitation as they unfold in the fynbos year (Hepburn and Jacot Guillarmod, 1991; also table (II). Similarly, Moritz (1986) showed that where there is a high risk of losing the queen (table II) then thelytoky by workers is favoured. Where this risk is lower then it becomes more advantageous for workers to produce drones. Since climatic conditions at the time of reproductive swarming in capensis can result in a sharply increased probability of queen loss, they may have supplied the selection pressure that favoured the fixation of the trait DELW in capensis. Beyond the escarpment of the interior are the arid lands with their own unique plant communities stretching as far north as latitude 25 and perhaps further. Elements of the life history of the bees that live there, scutellata, are equally attuned to the vagaries of these totally different circumstances (Fletcher, 1978; Anderson et al, 1983).

The barrier to the mixing of these populations is the border between the 2 regions at which there is a total discontinuity of physical and biological factors so that ecological variables are completely out of phase. It is likely that southerly movements of scutellata are heavily restricted by limited resources under normal conditions and virtually precluded in the drought decades of the wet-dry cycles which occur, particu- 
Table II. Biological characteristics of $A m$ capensis and $A m$ scutellata.

\begin{tabular}{|c|c|c|c|c|}
\hline Character & Capensis & Scutellata & Remarks & References ${ }^{a}$ \\
\hline $\begin{array}{l}\text { Worker } \\
\text { ovarioles }\end{array}$ & 10 & 5 & $\begin{array}{l}\text { Intermediate } \\
\text { in hybrid zone }\end{array}$ & Table I \\
\hline DELW gene & Present & Absent & $\begin{array}{l}\text { Present, hybrid } \\
\text { zone }\end{array}$ & Table 1 \\
\hline $\begin{array}{l}\text { Laying worker } \\
\text { progeny }\end{array}$ & $\begin{array}{l}\text { Diploid and } \\
\text { haploid }\end{array}$ & Haploid & $\begin{array}{l}\text { Diploid and haploid } \\
\text { in hybrid zone }\end{array}$ & Table I \\
\hline $\begin{array}{l}\text { Laying worker, } \\
\text { latency to }\end{array}$ & Short & Long & Values in Africa & 1,2 \\
\hline $\begin{array}{l}\text { Laying worker } \\
\text { has retinue }\end{array}$ & Yes & No & & 3,4 \\
\hline $\begin{array}{l}\text { Laying worker } \\
\text { pheromones }\end{array}$ & $\begin{array}{l}\text { Queen-like } \\
\text { 9-ODA } \\
\text { dominant }\end{array}$ & $\begin{array}{l}\text { Worker-like } \\
\text { 9-ODA } \\
\text { trace }\end{array}$ & & $5,6,27$ \\
\hline $\begin{array}{l}\text { Laying worker } \\
\text { types }\end{array}$ & $\begin{array}{l}\text { Pheromonally } \\
\text { queen-like, } \\
\text { lays eggs } \\
\text { or not; } \\
\text { worker-like, } \\
\text { lays eggs } \\
\text { or not }\end{array}$ & $\begin{array}{l}\text { Pheromonally } \\
\text { worker-like, } \\
\text { lays eggs } \\
\text { or not }\end{array}$ & & 5,6 \\
\hline $\begin{array}{l}\text { Queenless bees } \\
\text { fighting } \\
\text { syndrome }\end{array}$ & Variable & Absent & $\begin{array}{l}\text { Commoner in } \\
\text { western Cape }\end{array}$ & 1,7 \\
\hline $\begin{array}{l}\text { Queenless bees } \\
\text { cell building }\end{array}$ & Worker-size & Drone-size & & 8,9 \\
\hline $\begin{array}{l}\text { Queenless } \\
\text { broodless bees }\end{array}$ & $\begin{array}{l}\text { New queen } \\
\text { possible }\end{array}$ & $\begin{array}{l}\text { New queen } \\
\text { impossible }\end{array}$ & $\begin{array}{l}\text { Several sequences } \\
\text { possible in capensis }\end{array}$ & $8,10,11$ \\
\hline $\begin{array}{l}\text { Queenless bees, } \\
\text { acceptability } \\
\text { of new queen }\end{array}$ & $\begin{array}{l}\text { High } \\
\text { rejection }\end{array}$ & $\begin{array}{l}\text { High } \\
\text { acceptance }\end{array}$ & & 12,13 \\
\hline $\begin{array}{l}\text { Queen mating } \\
\text { flights, wind }\end{array}$ & Up to $14 \mathrm{~m} / \mathrm{s}$ & $5 \mathrm{~m} / \mathrm{s}$ & & 7 \\
\hline $\begin{array}{l}\text { Mating flights, } \\
\text { queen loss }\end{array}$ & High & Low & & 7 \\
\hline $\begin{array}{l}\text { Reproductive } \\
\text { dominance }\end{array}$ & Very high & Low & In Africa & $8,14,28$ \\
\hline
\end{tabular}




\begin{tabular}{|c|c|c|c|c|}
\hline $\begin{array}{l}\text { Invasiveness, } \\
\text { other races }\end{array}$ & High & Low & $\begin{array}{l}\text { In Africa, both } \\
\text { high for other } \\
\text { mellifera races }\end{array}$ & $7,8,14,15$ \\
\hline $\begin{array}{l}\text { Inhibition of } \\
\text { queen cells }\end{array}$ & $\begin{array}{l}\text { By queens } \\
\text { and laying } \\
\text { workers }\end{array}$ & $\begin{array}{l}\text { By queens } \\
\text { only }\end{array}$ & & $2,10,17$ \\
\hline $\begin{array}{l}\text { Inhibition of } \\
\text { worker ovarioles }\end{array}$ & $\begin{array}{l}\text { By queens } \\
\text { and laying } \\
\text { workers }\end{array}$ & $\begin{array}{l}\text { By queens } \\
\text { only }\end{array}$ & & 2,18 \\
\hline Colony growth & Sluggish & Rapid & & 10 \\
\hline $\begin{array}{l}\text { Absconding } \\
\text { migrations }\end{array}$ & Winter & Summer & In South Africa & 14,19 \\
\hline $\begin{array}{l}\text { Foraging } \\
\text { success }\end{array}$ & $\begin{array}{l}\text { High in } \\
\text { fynbos, } \\
\text { low elsewhere }\end{array}$ & $\begin{array}{l}\text { Low in fynbos, } \\
\text { high elsewhere }\end{array}$ & & $14,19,20$ \\
\hline $\begin{array}{l}\text { Temperature } \\
\text { regulation }\end{array}$ & $\begin{array}{l}\text { Clusters } \\
\text { well }\end{array}$ & $\begin{array}{l}\text { Clusters } \\
\text { poorly }\end{array}$ & $\begin{array}{l}\text { Capensis similar } \\
\text { to temperate } \\
\text { mellifera }\end{array}$ & 21 \\
\hline Docility & Very high & Very low & $\begin{array}{l}\text { Intermediate } \\
\text { in hybrid zone }\end{array}$ & $7,15,22$ \\
\hline $\begin{array}{l}\text { Worker } \\
\text { colouration }\end{array}$ & Blackish & Yellowish & Highly variable & $8,23,24$ \\
\hline Propolis use & High & Lowish & $\begin{array}{l}\text { Personal } \\
\text { observations }\end{array}$ & \\
\hline $\begin{array}{l}\text { Worker } \\
\text { tergal } \\
\text { gland }\end{array}$ & Present & Absent & & 25 \\
\hline mtDNA & $\begin{array}{l}430 \mathrm{bp} \\
\text { insert }\end{array}$ & $\begin{array}{l}270 \mathrm{bp} \\
\text { insert }\end{array}$ & $\begin{array}{l}\text { Absent from } \\
\text { European } \\
\text { mellifera races }\end{array}$ & 26 \\
\hline
\end{tabular}

a References. 1, Anderson, 1963; 2, Hastings, 1989; 3, Anderson, 1965; 4, Velthuis, 1985; 5, Ruttner et al, $1976 ; 6$. Crewe and Velthuis, 1980; 7, Tribe, 1983; 8, Onions, 1912; 9, Whiffler and Hepburn, 1991a; 10, Anderson et al, 1983; 11, Hepburn et al, 1988; 12, Lundie, 1929; 13, Buys, 1984; 14, Johannsmeier, 1983; 15, Davidson, 1933; 16, Rinderer et al, 1985; 17; Whiffler and Hepburn, 1991b; 18, Hepburn et al, 1991; 19, Hepburn and Jacot Guillarmod, $1991 ; 20$. Worswick, 1988; 21, Worswick, 1987; 22. Fletcher, 1978; 23, Guy, 1976; 24, Hepburn, 1989; 25, Billen et al, 1986; 26, Meusel and Moritz, 1991; 27, Crewe et al, 1991;28, Moritz and Hillesheim, 1985.

larly in the hybrid zone. Likewise, there has never been any migratory beekeeping that involves crossing over from the zone of one race into that of another race. Thus, capensis and scutellata are constrained ecologically as are the other biological races of mellifera in sub-Saharan Africa (Ruttner, 1988). The dynamics of the capensis 
Table III. Physical and biological characteristics of areas naturally occupied by capensis and of scutellata areas bordering on the fynbos.

\begin{tabular}{|c|c|c|c|}
\hline Character & Capensis & Scutellata & Remarks \\
\hline Topography a & $\begin{array}{l}\text { Mountains } \\
\text { to coastal }\end{array}$ & $\begin{array}{l}\text { Undulating } \\
\text { plains to } \\
\text { flat }\end{array}$ & $\begin{array}{l}\text { Border between } \\
\text { hybrid zone and } \\
\text { scutellata } \\
\text { mountainous }\end{array}$ \\
\hline Soils a & $\begin{array}{l}\text { Mainly rock, } \\
\text { undifferentiated }\end{array}$ & $\begin{array}{l}\text { Latosols, } \\
\text { clays, or } \\
\text { lime-rich }\end{array}$ & $\begin{array}{l}\text { Hybrid zones as } \\
\text { in scutellata }\end{array}$ \\
\hline Climate ${ }^{b}$ & Mediterranean & Semi-arid & $\begin{array}{l}\text { Hybrid zone } \\
\text { semi-arid }\end{array}$ \\
\hline $\begin{array}{l}\text { Temperature b } \\
\text { extremes and } \\
\text { fluctuation }\end{array}$ & Moderate & Severe & $\begin{array}{l}\text { Hybrid zone } \\
\text { severe }\end{array}$ \\
\hline Precipitation $b$ & $\begin{array}{l}\text { Winter to } \\
\text { year-round }\end{array}$ & Summer & $\begin{array}{l}\text { Precipitation } \\
\text { decreases on } \\
\text { west-east gradient }\end{array}$ \\
\hline $\begin{array}{l}\text { Wind } \\
\text { intensity b }\end{array}$ & Moderate to high & $\begin{array}{l}\text { Low to } \\
\text { moderate }\end{array}$ & $\begin{array}{l}\text { Hybrid zone as } \\
\text { in scutellata }\end{array}$ \\
\hline \multicolumn{4}{|l|}{ Winds } \\
\hline Summer & Southeast & Highly variable & $\begin{array}{l}\text { Hybrid zone as } \\
\text { in scutellata }\end{array}$ \\
\hline Winter & Northwest & Northwest & for winter and summer \\
\hline Biomes a & Fynbos & $\begin{array}{l}\text { Nama-Karoo and } \\
\text { grassland }\end{array}$ & $\begin{array}{l}\text { Hybrid zone as } \\
\text { in scutellata }\end{array}$ \\
\hline $\begin{array}{l}\text { Vegetation a } \\
\text { type }\end{array}$ & $\begin{array}{l}\text { Grassy, } \\
\text { dwarf shrub } \\
\text { shrub-woodland }\end{array}$ & $\begin{array}{l}\text { Grassy to } \\
\text { dwarf shrubland }\end{array}$ & $\begin{array}{l}\text { Hybrid zone as } \\
\text { in scutellata }\end{array}$ \\
\hline $\begin{array}{l}\text { Floristic c } \\
\text { diversity }\end{array}$ & Very high & Low/moderate & $\begin{array}{l}\text { Hybrid zone as } \\
\text { in scutellata }\end{array}$ \\
\hline $\begin{array}{l}\text { Floral c } \\
\text { endemism }\end{array}$ & Very high & Low/moderate & $\begin{array}{l}\text { Hybrid zone as } \\
\text { in scutellata }\end{array}$ \\
\hline \multicolumn{4}{|l|}{$\begin{array}{l}\text { Flowering }{ }^{d} \\
\text { cycles }\end{array}$} \\
\hline Peak & $\begin{array}{l}\text { Late winter and } \\
\text { spring }\end{array}$ & $\begin{array}{l}\text { Summer and } \\
\text { autumn }\end{array}$ & \\
\hline Low & $\begin{array}{l}\text { Summer and } \\
\text { mid-winter }\end{array}$ & Winter & \\
\hline
\end{tabular}

a Rutherford and Westfall, 1985; b Schulze, 1965; c Bond and Goldblatt, 1984; d Hepburn and Jacot Guillarmod, 1991. 
$x$ scutellata hybrid zone offer opportunities for natural experiments in genetics and evolution that are unparalleled by any other region in which honeybees occur.

\section{NOTE}

The distributions of capensis, scutellata and their hybrids (fig 2) are fully supported by our recent morphometric analysis of bees from the same localities listed in table I, the results of which all be published in due course. A recent synthesis of the ecology of the Fynbos Biome, natural home of capensis, is now available as follows: Cowling R (1991) The Ecology of Fynbos, Nutrients, Fire and Diversity. Oxford, Cape Town.

\section{ACKNOWLEDGMENTS}

We thank Professor RFA Moritz for his comments on the MS, $S$ van Noort for the allozyme data and $P$ Magnuson for assistance with the data. We especially thank Prof $F$ Ruttner for his sustained interest and encouragement.

\section{Résumé - Portrait de l'abeille du Cap.} En s'appuyant sur un vaste échantillonnage de colonies prélevées dans toute l'Afrique du Sud (fig 1), on définit la race Apis mellifera capensis, ou abeille du Cap, par 2 caractères essentiels, le caractère "œufs diploïdes pondus par les ouvrières» et un nombre élevé d'ovarioles chez les ouvrières (tableau I), et par une série d'autres caractéristiques biologiques. Elles comprennent, dans le cas de colonies orphelines, la possibilité latente de développer des ouvrières pondeuses et leur capacité à déclencher le comportement de cour à l'aide de substances semblables aux phéromones royales, les combats d'ouvrières entre elles, la construction des cellules et l'acceptation de reines introduites (tableau (I).
Cette race diffère aussi des autres par les vols nuptiaux, la dominance de reproduction, la propension à envahir les colonies des autres races et la capacité des ouvrières pondeuses à inhiber la construction des cellules royales et le développement ovarien chez les autres ouvrières (tableau II). Elle se distingue également par la croissance des colonies, la désertion, le butinage, la régulation de la température, la docilité, l'utilisation de la propolis et, dans une certaine mesure, par la couleur (tableau II).

A $m$ capensis est présente dans le biome fynbos, une formation végétale unique semblable au maquis de la région méditerranéenne, mais constituée de plantes totalement différentes. Cette région s'étend le long des côtes sud-ouest et sud de l'Afrique du Sud et est limitée à l'intérieur par 4 chaînes de montagnes, le Bokkeveld, Cedarberg, Swartberg et Suurberg (fig 2). A $m$ scutellata se rencontre plus au Nord et ses limites méridionales sont les chaînes de montagnes du Roggeveldberg, Nuweveldberg, Sneeuberg, Kikvorsberg, Bamboesberg, Stormberg et Drakensberg (fig 2). La région comprise entre la première chaîne de montagnes et la seconde est une zone d'hybridation entre les 2 races.

La barrière actuelle entre les 2 races (en fait la limite définissant l'extension d' $A$ $m$ scutellata vers le sud) présente des caractéristiques physiques et biologiques qui la définissent avec précision. Cette limite, qui est la frontière sud du grand Karoo, diffère radicalement du biome fynbos d' $A m$ capensis par la structure géologique, les sols, le climat (température, précipitation et vents), ainsi que par la composition, la diversité, l'endémisme et la phénologie de la végétation (tableau III). La définition et la répartition d' $A m$ capensis données ici tiennent compte de toutes les données connues. 
A $m$ capensis / article de synthèse/ comportement / physiologie / A m scutellata / biotope

\section{Zusammenfassung - Portrait der Kap-} biene (Apis mellifera capensis). Auf Grund einer umfassenden Probensammlung in der ganzen Südspitze von Afrika (Abb 1) wurde die Rasse der Kapbiene, Apis mellifera capensis vor allem nach zwei Hauptmerkmalen definiert, nämlich dem Merkmal diploide Eier von Arbeitsbienen und einer hohen Zahl von Ovariolen (Eischläuchen) bei Arbeiterinnen (Tabelle I), sowie nach einer Reihe anderer biologischer Eigenschaften. Diese umfassen bei weisellosen Völkern unter anderem die Latenzzeit bis zur Entstehung legender Arbeiterinnen sowie deren Fähigkeit, mittels königinnen-ähnlicher Pheromone die Bildung eines Hofstaates auszulösen, Kämpfe der Bienen untereinander, Zellbau und Annahme zugesetzter Königinnen (Tabelle II). Diese Rasse unterscheidet sich auch bei den Paarungsflügen, der Fortpflanzungsdominanz, ihrer Fähigkeit, in Völker anderer Rassen einzudringen sowie in der Fähigkeit legender Arbeiterinnen, die Ovarentwicklung bei anderen Arbeitsbienen und die Errichtung von Weiselzellen zu hemmen (Tabelle II). Unterscheidungsmerkmale dieser Rasse sind außerdem langsameres Volkswachstum, geringere Neigung zum Ausziehen, Besonderheiten des Sammelns und der Temperaturregulierung (Anpassung an die lokale Tracht, Bildung einer Wintertraube), besondere Sanftmut, stärkere Verwendung von kittshartz und (zu einem gewissen Grad) dunklere Körperfärbung (Tabelle II). A $m$ capensis kommt in der FynbosRegion vor, einer einzigartigen Pflanzengesellschaft ähnlich der niedrigen immergrünen Buschvegetation des Mittelmeergebietes, aber zusammengesetzt aus gänzlich anderen Pflanzen. Diese Region erstreckt sich entlang der Südwest- und Südküste Afrikas und ist gegen das Innere des Kontinents durch vier Bergzüge abgegrenzt, das Bokkeveld, Cedarberg, Swartberg und Suurberg (Abb 2). A m scutellata kommt weiter nördlich vor; ihre Südgrenze sind die Bergzüge des Roggeveldberg, Nuweveldberg, Sneewberg, Kikvorsberg, Bamboesberg, Stornberg und Drakensberg (Abb 2). Das Gebiet zwischen den ersten und den zweiten Bergzügen bildet eine Hybridzone zwischen den beiden Rassen. Die heutige Barriere zwischen den beiden Rassen (welche die südliche Begrenzung des Verbreitungsgebietes von A $m$ scutellata bildet) ist physikalisch wie biologisch scharf markiert. Diese Grenzlinie, gleichzeitig die Südgrenze der Großen Karoo, unterscheidet sich radikal von der Fynbos-Zone von $A$ m capensis in der Gestalt der Erdoberfläche, den Böden, dem Klima (Temperatur, Niederschlag und Wind) und der Zusammensetzung, Vielfalt, örtlichen Besonderheiten (Endemismen) und der Blütenbiologie der Pflanzenwelt (Tabelle III). Die hier für $A m$ capensis gegebene Definition und Verbreitung schließt alle bisher bekannten Daten ein.

Apis mellifera capensis / Übersicht / Verhalten / Physiologie / Apis mellifera scutellata / Biotop

\section{REFERENCES}

Anderson RH (1963) The laying worker in the Cape honeybee, Apis mellifera capensis. $J$ Apic Res 2(2), 85-92

Anderson RH (1965) A method for controlled queen-rearing in colonies of the Cape honeybee (Apis mellifera capensis). $S$ Afr J Agric Sci 8, 1163-1164

Anderson RH, Buys B, Johannsmeier M (1983) Beekeeping in South Africa. Bulletin No 394 , Department of Agriculture, Pretoria 
Billen JPJ, Dumortier KTM, Velthuis HHW (1986) Plasticity of honeybee castes. Naturwissenschaften 73, 332-333

Bond P, Goldblatt P (1984) Plants of the Cape Flora. J S Afr Bot supp/ No 13

Buys B (1984) Cape worker-bees dislike African virgin queens. $S$ Afr Bee J 56(3), 63

Crewe RM, Velthuis HHW (1980) False queens: a consequence of mandibular gland signals in worker honeybees. Naturwissenschaften 67, 467-469

Crewe RM, Wossler T, Allsopp MH (1991) Workers in queens clothing: why capensis workers become pseudoqueens. In: Bees and Beekeeping in Southern Africa (Anderson RW, Buys B, eds) Apimondia, Stellenbosch, 83-89

Davidson GP (1933) Apiculture in South Africa. Central News Agency, South Africa

Deacon J, Lancaster N (1988) Late Quartenary Palaeoenvironments of Southern Africa. Clarendon, Oxford

Deacon WJ, Hendey QB, Lambrechts JJ (1983) Fynbos Palaeoecology: A Preliminary Synthesis. CSIR, Pretoria

Fletcher DJC (1978) The African bee, Apis mellifera adansonii, in Africa. Ann Rev Entomol 23, 151-171

Guy RD (1976a) Whence the Cape bee? Part 1. $S$ Afr Bee J 48 (2), 7-8

Guy RD (1976b) Whence the Cape bee? Part 2. $S$ Afr Bee J 48 (3), 9-11

Hastings $H$ (1989) Two aspects of the biology of an African honeybee Apis mellifera scutellata (Hymenoptera, Apidae): laying workers and colony defence behaviour. Ph D thesis, University of Natal, Pietermaritzburg

Hemmling C, Koeniger N, Ruttner F (1979) Quantitative Bestimmung der 9oxodecensäure im Lebenszyklus der Kapbiene (Apis mellifera capensis Esch). Apidologie 10, 227-240

Hepburn HR (1989) Capensis in the Eastern Cape. S Afr Bee J 61(4), 87-89

Hepburn HR (1991) What and where is the Cape bee - an interim report. In: Bees and Beekeeping in Southern Africa (Anderson $\mathrm{RH}$, Buys $\mathrm{B}$, eds) Apimondia, Stellenbosch, 74-82
Hepburn HR, Crewe RM (1990) Defining the Cape honeybee: reproductive traits of queenless workers. S Afr J Sci 86, 524-527

Hepburn HR, Jacot Guillarmod A (1991) The Cape honeybee and the fynbos biome. $S$ Afr $J$ Sci 87, 70-73

Hepburn HR, Nefdt RJC, Whiffler LA (1988) Queen loss in the Cape honeybee: the interactions of brood, laying workers (false queens?) and queen cells. S Afr J Sci 84 , 778-780

Hepburn HR, Magnuson P, Herbert L, Whiffler LA (1991) The development of laying workers in the Cape honeybee. J Apic Res (in press)

Johannsmeier MF (1983) Experiences with the Cape bee in the Transvaal. S Afr Bee J 55, 130-138

Kerr WE, Portugal Araujo V de (1958) Racas de abelhas de Africa. Garcia de Orta 6, 53-59

Lambrechts JJN (1979) Geology, geomorphology and soils. In: Fynbos Ecology: a Preliminary Synthesis (Day J, Siegfried W, Louw GN, Jarmna ML, eds) CSIR, Pretoria, 16-26

Lundie AE (1929) The rearing of queen-bees. Bull Dept Agric Un S Afr No 6

Mackensen $O$ (1943) The occurrence of parthenogenetic females in some strains of honeybees. J Econ Entomol 36, 465-470

Moritz RFA (1986) Two parthenogenetical strategies of laying workers in honeybee populations (Apis mellifera L). Entomol Gen 11, 159-164

Moritz RFA (1991) Natural and artificial selection in the Cape honeybee Apis mellifera capensis. In: Bees and Beekeeping in Southern Africa (Anderson RH, Buys B, eds) Apimondia, Stellenbosch, 63-73

Moritz RFA, Kauhausen D 1984. Hybridization between Apis mellifera capensis and adjacent races of Apis mellifera. Apidologie 15, 211/222

Moritz RFA, Hillesheim E (1985) Inheritance of dominance in honeybees (Apis mellifera capensis Escholtz). Behav Ecol Sociobiol 17, 87-89

Nunamaker RA, Wilson WT (1981) Comparison of $\mathrm{MDH}$ allozyme patterns in the African honey bee (Apis mellifera adansonii $L$ ) and 
the Africanized populations of Brazil. J Kans Entomol Soc 54, 704-710

Nunamaker RA, Wilson WT, Haley BE (1984) Electrophoretic detection of Africanized honey bees (Apis mellifera scutellata L) in Guatemala and Mexico based on male dehydrogenase allozyme patterns. I Kans Entomol Soc 57, 622-631

Onions GW (1912) South African "fertile worker bees". S Afr Agric J 1, 720-728

Onions GW (1914) South African "fertile" worker bees. Agric J Un S Afr 7, 44-46

Rinderer TE, Hellmich RL, Danka RG, Collins AM (1985) Male reproductive parasitism: a factor in the Africanization of European honey-bee populations. Science 228, 1119-1121

Rutherford MC, Westfall RH (1985) Biomes of southern Africa - an objective categorization. Mem Bot Surv S Afr No 54

Ruttner F (1977) The problem of the Cape bee (Apis mellifera capensis Escholtz): parthenogenesis - size of population - evolution. Apidologie 8, 281-294

Ruttner F (1988) Biogeography and Taxonomy of Honeybees. Springer, Berlin

Ruttner F, Koeniger N, Veith HJ (1976) Queen substance bei eierlegenden Arbeiterinnen der Honigbiene Apis mellifica L. Naturwissenschaften 63, 434

Schuize BR (1965) Climate of South Africa. No 8. Weather Bureau, Department of Transport, Pretoria

Smith DR (1988) Mitochondrial DNA polymorphisms in five old world subspecies of honeybees and in new world hybrids. In: Africanized Honey Bees and Bee Mites (Needham GR, Page RE, Delfinado-Baker M, Bowman CE, eds) John Wiley, New York ribe GD (1981) Cape honeybee behavour. $S$ Afr Bee J 53, 10-12

Tribe GD (1983) What is the Cape bee? S Afr Bee J 55, 77-87

Velthuis HHW (1985) The honeybee queen and the social organization of her colony. Fortschr Zool 31, 343-357

Velthuis HHW, Ruttner F, Crewe RM (1990) Differentiation in reproductive physiology and behaviour during the development of laying worker honey bees. In: Social Insects (Engels W, ed) Springer, Berlin

Verma S, Ruttner $F$ (1983) Cytological analysis of the thelytokous parthenogenesis in the Cape honeybee (Apis mellifera capensis Escholtz). Apidologie 14, 41-57

Whiffler LA, Hepburn HR (1991a) The queen in relation to wax secretion in honeybees. $J$ Comp Physiol (in press)

Whiffler LA, Hepburn HR (1991b) Inhibition of queen cell construction in the Cape honeybee, Apis mellifera capensis. Apidologie 22, 229-236

Worswick PV (1987) Comparative study of colony thermoregulation in the African honeybee Apis mellifera adansonii Latreille and the Cape honeybee, Apis mellifera capensis Escholtz. Comp Biochem Physiol 86A, 95-102

Worswick PV (1988) Comparison of nectar foraging efficiency in the Cape honeybee, Apis mellifera capensis Escholtz and the African honeybee, Apis mellifera adansonii Latreille in the Western Province. S Afr J Zool 23, 124-127

Woyke J (1986) Sex determination. In: Bee Genetics and Breeding (Rinderer $\mathrm{T}$, ed) Academic Press, New York 